\title{
Caim como paradigma de violência em Gn 4,1-16
}

\author{
Orientador: Leonardo Agostini Fernandes \\ Mestrando: Leandro Edmar Nandi \\ Área de Concentração: Teologia Bíblica
}

Linha de Pesquisa: Análise e Interpretação dos Textos do Antigo e Novo Testamento

Basta um olhar atento para perceber o impulso de violência que age como força destrutiva na humanidade e nas sociedades de todas as épocas. $\mathrm{O}$ 'violar' e o 'corromper' parecem ser traços constantes na vida social, desde suas formas mais expressivas até as mais sutis. Este trabalho adentra o texto de $\mathrm{Gn}$ 4,1-16, buscando compreender nele o drama de Caim que não consegue viver a fraternidade com seu irmão. Caim está presente, ao longo de gerações e no imaginário popular, como presença arquetípica do conflito do ser humano com o seu semelhante. Este personagem carrega em si o simbolismo das forças violentas e de suas consequências quando se permite que essas forças dominem sobre as ações. Por isso, sua figura perpassa o tempo em sua sina, "vagando errante" em cada indivíduo confrontado com seus limites e seus impulsos. Conhecer os relatos bíblicos e seus significados permite aprofundar a própria história humana e suas relações com o sagrado e com o profano. Buscar as raízes significativas destes relatos é contribuir com um comunicativo canal capaz de trazer, para o homem hodierno, a sagrada sabedoria do antigo Israel, em seus paradigmas e em seus paradoxos. Desse modo, a investigação visa perceber quais as forças motrizes que geraram a ação violenta no personagem de Caim, elucidando, assim, aspectos da origem da violência presente no ser humano.

Palavras-chave: Teologia. Bíblia. Exegese. 